\title{
Community-based participatory irrigation management at local government level in Ghana
}

\section{Commonwealth Journal of Local Governance \\ Issue 15: June 2014 \\ http://epress.lib.uts.edu.au/ojs/index.php/cjlg}

\section{Braimah}

Kwame Nkrumah University of Science and Technology Kumasi, Ghana

\section{R. S. King}

Kwame Nkrumah University of Science and Technology Kumasi, Ghana

\section{M. Sulemana \\ EDMAT Foundation, Tamale}

\begin{abstract}
Ghana has attempted to decentralise the management of irrigation schemes to communities at local government level. This study examines the existing local participatory management structures and the principles of the Participatory Irrigation Management (PIM) strategy designed to promote sustainable management of irrigation schemes in Ghana. Two community-based irrigation projects, Bontanga and Golinga in the Northern Region of Ghana were selected for the research. The study demonstrated that farmers' participation was minimal and limited to the discussion of irrigation service charges at the expense of other issues related to the sustainability of the projects/schemes. The study also established that there was less participation of women, and more than half of all the crop farmers on the two irrigation projects were reluctant to assume additional responsibilities without remuneration. The study therefore concluded that the sustainability of the PIM strategy depends on the adoption of an integrated management approach involving all stakeholders including local government, with appropriate incentives.
\end{abstract}

Keywords: Participation, irrigation, management, Golinga, Bontanga,

\section{Introduction}

The continued deterioration of irrigation infrastructure coupled with mounting cost of centrally managed irrigation projects compelled the government of Ghana to adopt the Participatory Irrigation Management (PIM) strategy in the 1990s. The PIM strategy is viewed as the irrigation version of decentralised and user-centered approach to general infrastructure provision and management including also the management of common pool resources. At the heart of the PIM strategy is the argument that local users of irrigation resources, if empowered as a group to participate actively in the management of water resources, have the incentive to manage it more efficiently and sustainably than a wholly centrally financed government agency (Vermillion, 1997). 
With the PIM policy instrument in Ghana, the continuing burden of rehabilitation and modernisation of irrigation infrastructure is subsumed under the operations and maintenance costs borne by the beneficiary farmers or met by special projects. This presumption is however not based on any empirical evidence or theoretical foundation. It is anticipated that the strategy will enable local farmers to operate according to their customary (traditional) rules and cultural norms, while the central government experiences less financial responsibility and reduced cost in operations and management.

Several years after the implementation of the PIM strategy in Bontanga and Golinga there appears to be challenges that could undermine the sustainability of the schemes. They include weak farmerbased organizations (FBOs), perpetuation of land allocation arrangements that continue to discriminate against women farmers, and the achievement of unsatisfactory results in accordance with the principles of the PIM strategy. This study sought to examine the functions of the basic participatory management structures and the application of the PIM strategy to determine what was responsible for the challenges mentioned above.

\section{Objectives of the study}

The main objective of the study was to examine the sustainability of participatory management structures established on the premises of PIM. The specific objectives were as follows:

- $\quad$ To examine the basic participatory management structures and their functions in communitybased irrigation management;

- To investigate the application of the principles of PIM in the management of the Bontanga and Golinga community-based irrigation schemes;

- To establish the local socio-political forces that foster or impede community-project relationship in PIM; and

- $\quad$ To suggest the way forward for sustaining the PIM strategy in the study areas.

\section{Research methodology}

This research fundamentally used both quantitative and qualitative data to analyse the operationalisation of the Irrigation Development Authority (IDA) Regulations, 1987 (L.I. 1350) which cover the rights and responsibilities of the irrigation crop farmers, the operations and maintenance of the irrigation facilities, the functions of the local participatory structures and the application of selected basic principles of PIM. 


\section{Sample size determination}

The total number of farmers in the two irrigation projects was 675 (525 in Bontanga and 150 in Golinga) of whom only 23 were females. The sample size of farmers for the study was determined by the mathematical formula below with a confidence level of $90 \%$ and an error tolerance level of 10\%:

$$
\boldsymbol{n}=\frac{\boldsymbol{N}}{1+\boldsymbol{N}(\boldsymbol{e})^{2}}, \quad(\mathrm{n}=\text { sample size } ; \mathrm{N}=\text { population of farmers; } \mathrm{e}=\text { margin of error })
$$

In this study, $\mathrm{N}=675$ and $\mathrm{e}=0.10$, and so $\mathrm{n}=\frac{675}{1+675(0.10)^{2}}=87$.

\section{Sampling and sampling techniques}

A combination of both probability and non-probability sampling techniques were employed in the selection of the 87 farmers sampled. The sample size was proportionately distributed between the two projects areas. Ultimately 85 farmers were interviewed because the two farmers could not be reached after several call backs; 59 (69\%) from Bontanga and 26 (31\%) from Golinga.

The 85 farmers were made up of $62(73 \%)$ men and $23(27 \%)$ women. All women famers were included in the sample because their number was very small. The stratified sampling technique was then used to distribute farmers serving on committees to their respective existing committees using each committee as a stratum. The stratification was done because of the differentiated functions performed by the different committees and for convenience. The advantage the stratified sampling offered was that it ensured that the resulting sample was distributed in the same way as the population in terms of the stratification criterion. In each committee, purposive sampling was then used to select the number of farmers from each committee for the interview.

Simple random sampling was then used to select the farmers who did not belong to committees, because the farmers who did not belong to committees formed a homogenous group. Also, farmers who were executives of the Farmers' Association but not committee members were purposively selected and interviewed. The same sampling procedure was used in both irrigation schemes. The two project officers were also interviewed. Thus, the final sample size for the study comprised 85 farmers, 30 of whom were committee members and 55 were non-committee members and 40 were executives of various committees.

A semi-structured interview guide and a questionnaire were then used as instruments for data collection. In-depth interviews were employed to collect the required data from the 'non-committee' farmers. The questionnaires were administered to the project officers. The data collected from both primary and secondary sources were then collated, synthesized and analyzed using both qualitative and quantitative approaches to draw inferences and conclusions. 


\section{Profiles of the Bontanga and Golinga irrigation projects}

The Bontanga Irrigation Project is a large-scale gravity-fed scheme, and the largest northern Ghana. It is located at Bontanga in the Tolon-Kumbungu District, $34 \mathrm{~km}$ north west of Tamale, the regional capital of the Northern Region of Ghana. The scheme can cover a potential area of 800 hectares with 450 hectares irrigable land covered at present, of which 240 hectares is used for lowland rice cultivation and 210 hectares for upland vegetable production. Presently, there are 14 communities that farm within the Bontanga Irrigation Project area. The farmer population on the project as at the year 2012 was 525 (11 women) and they were organized into a cooperative made up of 10 farmer-based organizations (FBOs). The average farm holding size on the project is 0.6 hectares. The main crops cultivated within the project area include rice, maize, onion, pepper, tomato and okro (The Republic of Ghana, 2012; Ministry of Agriculture, 2011).

The Golinga Irrigation Project is a medium scale gravity-fed scheme located at Golinga also in the Tolon-Kumbungu District. The project is served by the Kornin River. The scheme has a potential coverage of 100 hectares of which 40 hectares of land is presently used as irrigable land. The vegetables are produced only in the dry season from October to April while rice is produced both in the dry and wet seasons. Presently, there are five communities that farm at the Golinga Irrigation Project's area. The farmer population on the scheme in 2012 was 150 (with 12 women) organized into a cooperative made up of five FBOs. The average farm holding size on the project is 0.2 hectares. There are also seven committees on the project which perform different responsibilities. The farmers on this project cultivate the same crops as those on the Botanga project. Figure 1 is a map of the Tolon-Kumbungu district showing the locations of the Bontanga and Golinga Irrigation projects. 
Figure 1: Tolon-Kumbungu District: Locations of Bontanga and Golinga Irrigation Schemes.

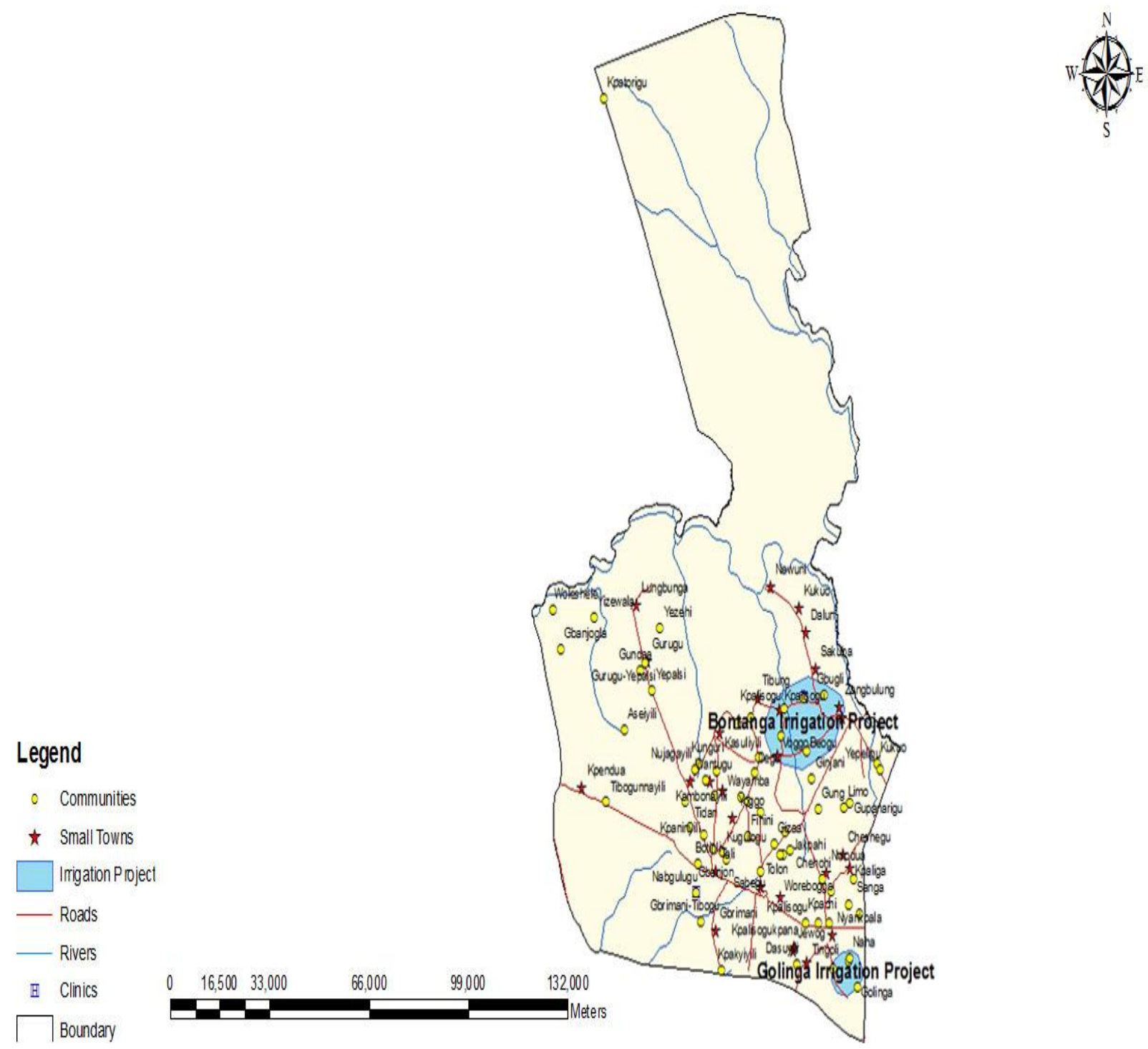

Source: Energy Commission (2011).

\section{Participatory irrigation management in perspective}

Under the PIM strategy farmers' organizations were presumed to share responsibility for the management of irrigation facilities. This is because the PIM strategy proposes that, as practical as possible, end users of irrigation resources should be involved in all aspects and at all levels in the management of irrigation facilities (Peter, 2004). After adopting the PIM strategy the need for a legal framework for the advancement of the strategy was realized. Furthermore some concerns were expressed about including in the irrigation management the relevant local participatory structures to take care of some essential issues including the rights, responsibilities and powers of the beneficiary farmers and their communities. It became evident that without these frameworks, there would be no prospects for the sustainability of the PIM strategy. 
According to Lamptey et al. (2011) the absence of a legal framework resulted in a situation where neither farmers nor the government took responsibility for the management of irrigation districts. This led partly to the stagnation of Ghana's irrigated agriculture. To overcome these challenges or inadequacies, the government of Ghana and Japan International Cooperation Agency (JICA), through the Ghana Irrigation Development Authority (GIDA), decided to implement in all the 22 irrigation districts $^{1}$ in Ghana, a project aimed at improving the Farmer Participatory Irrigation Management (FAPIM) guided by the Japanese PIM model (see Tanaka and Sato (2002). The project started in 2004 and was completed in 2006. According to JICA (2004), the project's purpose was to improve the framework for the implementation of the participatory irrigation management based on the new system and to enhance the role and ability of GIDA to manage irrigated agriculture. The specific activities implemented included the formulation of a proposal for a system that covered the conclusion of a model agreement paper on the management of irrigation facilities between GIDA and the individual farmers' organizations throughout Ghana, training for the farmers and support for implementing action plans.

Following this sequence of events, the National Irrigation Policies, Strategies and Regulatory Measures for the year 2010 emphasised the sharing of GIDA's responsibility with farmers' in irrigation management in line with PIM. This demonstrated the government's commitment to the decentralization of irrigation services at the local government level and private sector participation from individual farmers to commercial operators (Lamptey et al. 2011). These policies strongly demanded that the irrigation sector institutions adhere to the principle of subsidiarity, with management responsibilities of public irrigation infrastructure devolved to users at the local level. Thus the PIM strategy of community ownership and management is similar to the principles espoused by Karikari (1996) and Yelbert (1999) in Braimah and Fielmuah (2011) where the community has legal ownership and control of the services.

\section{Conceptual framework for sustainable participatory irrigation management}

The adoption and implementation of the PIM strategy requires national orientation and regulations for decentralised irrigation management. This will provide government the opportunity to shed off part of its financial responsibilities and allow the irrigation sector institutions to expand the frontiers of decentralised participatory irrigation development and management. As can be seen in figure 2, with the right national orientation, irrigation policies are sent down through the regional to the project level for implementation with the expected outcome being sustainable PIM.

\footnotetext{
${ }^{1}$ Local governments in Ghana are referred to as metropolis, municipal or district assemblies, depending on their sizes. The district assemblies are the smaller local government structures in Ghana.
} 
Moved by the need for institutional and regulatory frameworks in support of irrigation, the government launched a draft national irrigation policy in 2006. Under the policy, the guiding principles of decentralisation and subsidiarity were considered critical (The Republic of Ghana, 2006). In keeping with consistency and following expert review of the policy in 2007, Cabinet finally approved the comprehensive irrigation policy on $30^{\text {th }}$ June 2010.

\section{Institutional/project management level}

According to the current irrigation policy of Ghana, GIDA is required to adhere to the principle of subsidiarity and the PIM strategy by devolving the management responsibility of irrigation infrastructure to users/farmers as much as possible, with farmers participating in decision making at all levels. At the project level, farmers are involved in management through their participation in the activities of both their associations and their respective farmer-based organisations or committees so formed as illustrated in figure 2. However, for these participatory structures to become sustainable, their activities should be underpinned by some basic principles of PIM.

The literature reviewed does not recommend a one-size-fit all set of PIM principles for countries and places. For the purpose of this study, and from review of the PIM principles, the following basic principles for sustaining PIM at the study projects were considered feasible (Yoder, 1994 and Sato et al. 2007 cited in Hamada \& Samad, 2011):

- Role casting to reflect farmers' awareness of their mandate, responsibilities and rights;

- Equity in water allocation including costs and benefit sharing;

- Transparency in the management of water fees (funds); and

- Representation (voice in decision making). 
Figure 2: A Conceptual Framework for Sustainable Participatory Irrigation Management

NATIONAL

ORIENTATION

BASIC

PRINCIPLES OF

PIM

COMMUNITY

ORIENTATION

(Supportive \& participatory)

OUTCOME

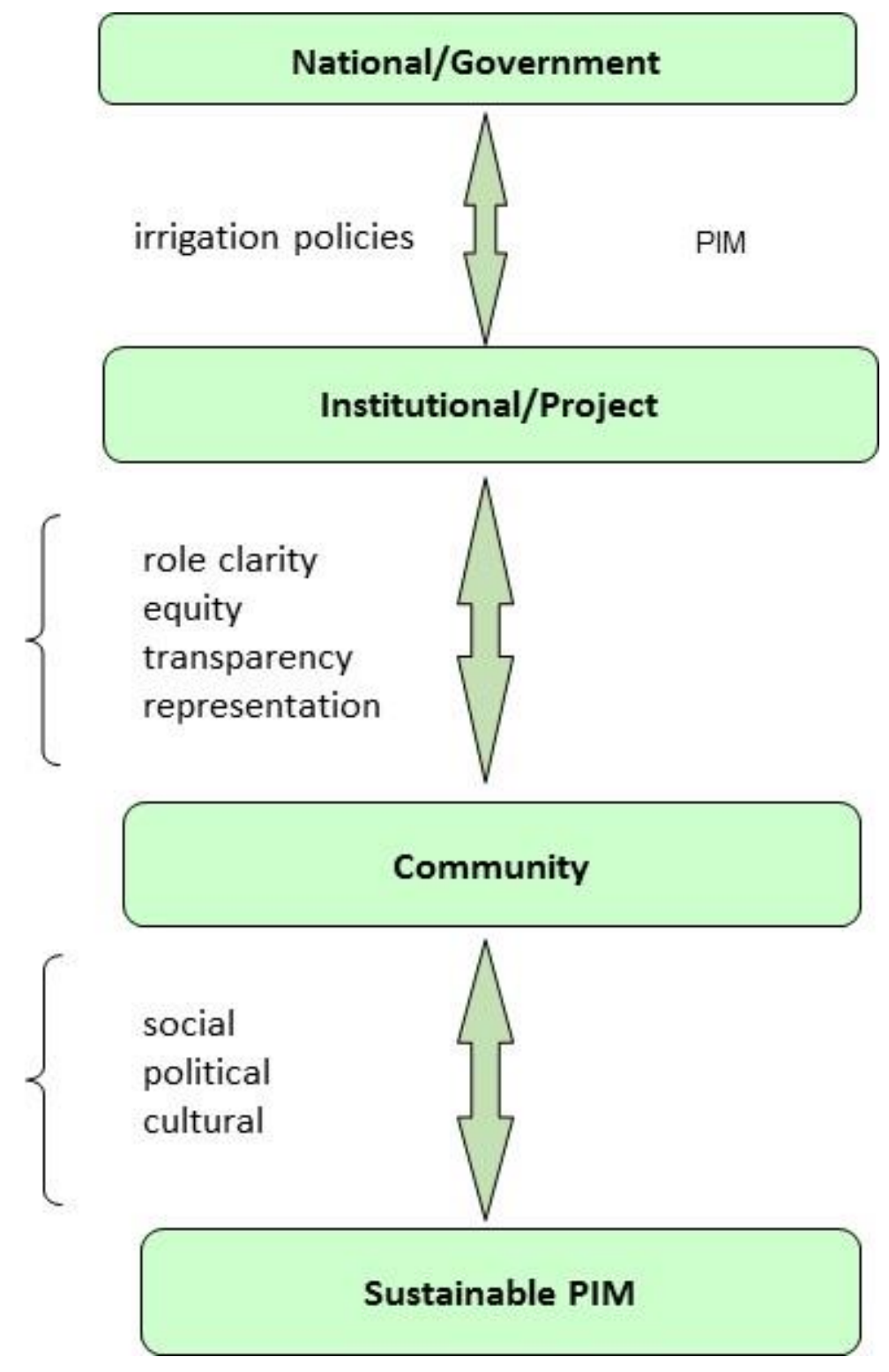

Source: Authors' Construct 


\section{Community level orientation (participation and cooperation)}

Since irrigation projects/schemes in the districts are located within communities they cannot be entirely insulated against social, cultural and political influences. Therefore, irrigation project managers are expected to see the host communities as an integral part of the irrigation systems if the PIM strategy is to succeed. This implies establishing and maintaining positive relationships with identifiable local socio-political groupings that foster cooperation in their respective communities. The existence of good community-project relationships can be used to resolve conflicts related to land access and tenure at the projects levels. Figure 2 illustrates a conceptual framework for sustainable PIM. It is also at this level that both the project beneficiaries and community members need to be aware pf the importance of ensuring sustainability of water supplies, in view of looming global problems related to water stress and environmental problems resulting from climate change, and the implication of these for the irrigation schemes and livelihoods of the farmers people.

\section{Participatory management structures at Bontanga and Golinga Irrigation Projects}

All farmers on each project were members of the respective Farmers Associations. Under the farmers' associations are committees established to promote farmers' participation in the operation and maintenance of the projects. Both the Farmers Associations and the committees draw their power and functions from the Participatory Structure and Functions of IDA 1987 (L.I. 1350), which makes the political head of the local governments the Chairpersons of the IDA functions as shown in Table 1.

Table 1: Participatory structures and their functions (L.I. 1350) Source: Field survey, 2012

\begin{tabular}{|c|c|c|}
\hline $\begin{array}{l}\text { Management } \\
\text { Arrangement }\end{array}$ & Membership & Functions of the Committee \\
\hline $\begin{array}{l}\text { Lands } \\
\text { Allocation } \\
\text { Committee }\end{array}$ & $\begin{array}{l}\text { (i) District Chief Executive (DCE)- Chairman } \\
\text { (ii) One representative of the Chief Executive of } \\
\text { the irrigation Authority } \\
\text { (iii) The irrigation project manager (Secretary) } \\
\text { (iv) One representative of the Traditional Council } \\
\text { within the area } \\
\text { (v) Two representatives of the Farmers' } \\
\text { Association of the irrigation project }\end{array}$ & $\begin{array}{l}\text { (i) Allocation of land to full-time farmers } \\
\text { on the irrigation project } \\
\text { (ii) Re-allocation of land that farmers fail to } \\
\text { cultivate within a year }\end{array}$ \\
\hline $\begin{array}{l}\text { Agricultural } \\
\text { Committee }\end{array}$ & $\begin{array}{l}\text { (i) Heads of Technical Departments of the } \\
\text { Management } \\
\text { (ii) Two representatives of the Farmers' } \\
\text { Associations }\end{array}$ & $\begin{array}{l}\text { (i) Planning and implementation of } \\
\text { agronomic practices } \\
\text { (ii) Protection of the irrigation network } \\
\text { (iii) Ensuring that farmers- (a) use the land } \\
\text { for the purpose specified in the } \\
\text { Agreement (b) do not transfer or sublet } \\
\text { land allocated to them }\end{array}$ \\
\hline $\begin{array}{l}\text { Disciplinary } \\
\text { Committee }\end{array}$ & $\begin{array}{ll}\text { (i) } & \text { Five elected senior management staff } \\
\text { (ii) } & \text { Two elected representatives of the Association }\end{array}$ & $\begin{array}{l}\text { Investigates infringements or alleged } \\
\text { infringements of the terms of the Agreement } \\
\text { and impose appropriate penalty when } \\
\text { necessary }\end{array}$ \\
\hline $\begin{array}{l}\text { Appeals } \\
\text { Committee }\end{array}$ & $\begin{array}{l}\text { (i) Chairman of the GIDA Board } \\
\text { (ii) Chief Executive of the Authority } \\
\text { (iii) Deputy Chief Executive of GIDA }\end{array}$ & $\begin{array}{l}\text { Considers cases of appeal arising out of the } \\
\text { decisions of the Disciplinary Committee }\end{array}$ \\
\hline $\begin{array}{l}\text { Farmers } \\
\text { Association }\end{array}$ & $\begin{array}{l}\text { A person elected by the members from among } \\
\text { themselves shall be the Chairman of the Association }\end{array}$ & $\begin{array}{l}\text { (i) Represents members in all } \\
\text { transactions with private and Gov't } \\
\text { Agencies concerning the project } \\
\text { (ii) Participates in the business of the } \\
\text { Management } \\
\text { (iii) Acts as an arbitrator in disputes } \\
\text { involving members of the Association }\end{array}$ \\
\hline
\end{tabular}


At the project level, there are Maintenance, Finance, Marketing and Women's Committees whose powers and functions are defined under the powers of the Farmers Association as per the L.I 1350 and the General Provisions under the PIM strategy. The Maintenance Committee is specifically concerned with mobilizing labour for the repairs and maintenance of outlets and lateral canals, while the Finance Committee takes part in the management of transactions relating to the accounts of the Associations. The Marketing Committee takes up the challenge of identifying and linking the irrigation crop farmers with prospective buyers of their farm produce. The Women's Committee is responsible for handling issues that affect the wellbeing and welfare of women crop farmers in the scheme. Also at the project level, the farmers form coalitions to take advantage of opportunities that may come their way. The Farmers Associations organise the committees in order to properly manage the farmers' part of the shared responsibilities of operations and maintenance

According to the PIM strategy, Ghana Irrigation and Development Authority's Operations and Maintenance responsibilities include the following:

- $\quad$ Formulating operational plans based on cropping calendar, irrigation water requirement and water delivery schedule;

- Discharging appropriate water at the check gate(s) of the main canals based on the delivery system;

- $\quad$ Monitoring and recording the discharge data of irrigation water at the check gate(s)

- $\quad$ Making the discharge record available to the Farmers' Cooperative;

- $\quad$ Preparing and implementing annual repair and maintenance plans;

- Monitoring regularly the implementation of repair and maintenance plans prepared by Farmers' Cooperative/Union of FBOs; and

- $\quad$ Conducting training for Farmers' Cooperative/Union of FBOs for the development of their capacity on financial arrangement.

With respect to the Financial Arrangement, GIDA's assigned responsibilities include, but not limited to the following:

- $\quad$ Preparing a budget to implement the annual operations and maintenance plan assigned to GIDA (1.5\% of initial cost at least);

- $\quad$ Determining the Irrigation Service Charge (ISC) together with the ISC committee;

- Monitoring the progress of irrigation service charge collection;

- Inspecting and reconciling jointly with Farmers' Cooperative/Union of FBOs the account books of the cooperative, as well as ISC collection and its use;

- Informing the Farmers Cooperatives on any findings in these activities;

- $\quad$ Issuing GIDA's official receipts for all payments made by famers and the cooperative;

- Depositing the ISC with the Treasurer of the Farmers' Cooperative/Union of FBOS 
For the purpose of Operation \& Maintenance the responsibilities assigned to the Farmers' Cooperative/Union of FBOs are as follows:

- $\quad$ Preparation of operational plans;

- $\quad$ Communicating the irrigation water delivery plans to the members;

- $\quad$ Selection of water bailiff from members to operate the turnout(s);

- Distribution of irrigation water equitably to the members according to the irrigation schedule;

- $\quad$ Safeguarding the water rights of all the members;

- Monitoring and recording the discharge data of irrigation water on measuring points;

- $\quad$ Preparation and implementation of the annual repair and maintenance plans; and

- Organisation of regular meetings to discuss the status of facilities and identify problems.

The Farmers' Cooperative/Union of FBOs responsibilities with regard to Financial Arrangements include the following:

- $\quad$ Making seasonal annual financial plans based for operation, repair and maintenance;

- $\quad$ Selection of ISC collectors and ensuring the collection of ISC from members on schedule;

- $\quad$ Payment of the amount of $10 \%$ of ISC to GIDA Project Office

- $\quad$ Receiving GIDA's official receipts of ISC;

- Maintaining and updating the account book, accessible to GIDA for regular and spot audit;

- $\quad$ Providing members with reports of ISC collection and use;

- $\quad$ Organising general meetings to discuss ISC

On cost sharing arrangement (i.e. capital build-up for future rehabilitation), the following are jointly agreed:

- $\quad$ GIDA and Farmers Cooperative/Union of FBOs contribute towards capital cost for future rehabilitation programme

- $\quad$ The ratio of cost sharing is determined through consultation with both parties

- The portion of rehabilitation fund contributed by the Farmers Cooperatives shall be kept in their own account as "capital build-up".

\section{Farmers willingness to assume additional responsibility in PIM}

Farmers' willingness to assume additional responsibilities is key to sustaining their participation in PIM. However, at the project level $68 \%$ of the farmers were not willing to take on additional responsibilities on the projects, citing lack of financial incentives as the reason. For instance, they mentioned the work of lateral and block leaders who are also farmers but are selected to take charge of the leakages and blockades to ensure free flow of water to the irrigated fields but it attracts no allowance. Table 2 below indicates the results.

Table 2: Farmers' willingness to assume additional responsibility

\begin{tabular}{|l|c|c|c|c|}
\hline \multirow{2}{*}{ Name of Project } & \multicolumn{2}{|c|}{ Willing } & \multicolumn{2}{c|}{ Not Willing } \\
\cline { 2 - 5 } & No & $\%$ & 40 & 68 \\
\hline Bontanga & 19 & 32 & 18 & 69 \\
\hline Golinga & 8 & 31 & $\mathbf{5 8}$ & $\mathbf{6 8}$ \\
\hline Total & $\mathbf{2 7}$ & $\mathbf{3 2}$ & No & $\%$ \\
\hline
\end{tabular}

Source: Author's field survey, May 2012 


\section{The basic principles of PIM at Bontanga and Golinga: equity, cost \& benefit sharing}

Some of the farmers thought that they could obtain water for their crops and receive their share of the irrigation benefits without participation in the management of the schemes. From the various reasons given by the farmers, it is clear that most of the farmers tend to agree that the payment of irrigation service charges alone is sufficient to guarantee allocation of water by the irrigation facility. Others argue logically that only farmers who participate in the activities of their Association should receive water and the other benefits of the irrigation scheme. The later also demonstrates a sense of ownership (participatory management) of the projects, contrary to the former. Thus, adhering to the latter should in principle increase the Association's membership, which should reflect on the size of the Association's 'Water Fee' funds and the 'capital build-up' account. This should ultimately result in stable financial conditions for the FBOs (Hamada \& Samad, 2011).

With respect to cost sharing, the ultimate criterion is the farm holding size. This practice adds another criterion of cost sharing to evidence from a reported case of Pongsak Muang Fai irrigation system in northern Thailand, where the members share cost based on farm intakes (Ouvichit et al. 2008, cited in Hamada \& Samad 2011). At the project level, over $60 \%$ of the farmers agreed that equity was applied in water allocation and in cost and benefit sharing with the highest rating being cost sharing. Thus, this suggests that equity in cost sharing is one of the most important principles in irrigation management. It thus supports sustainable PIM especially the small and medium scale ones, as shown in Figure 3.

Figure 3: Bar chart showing equity in selected issues at the projects Source: Author's construct

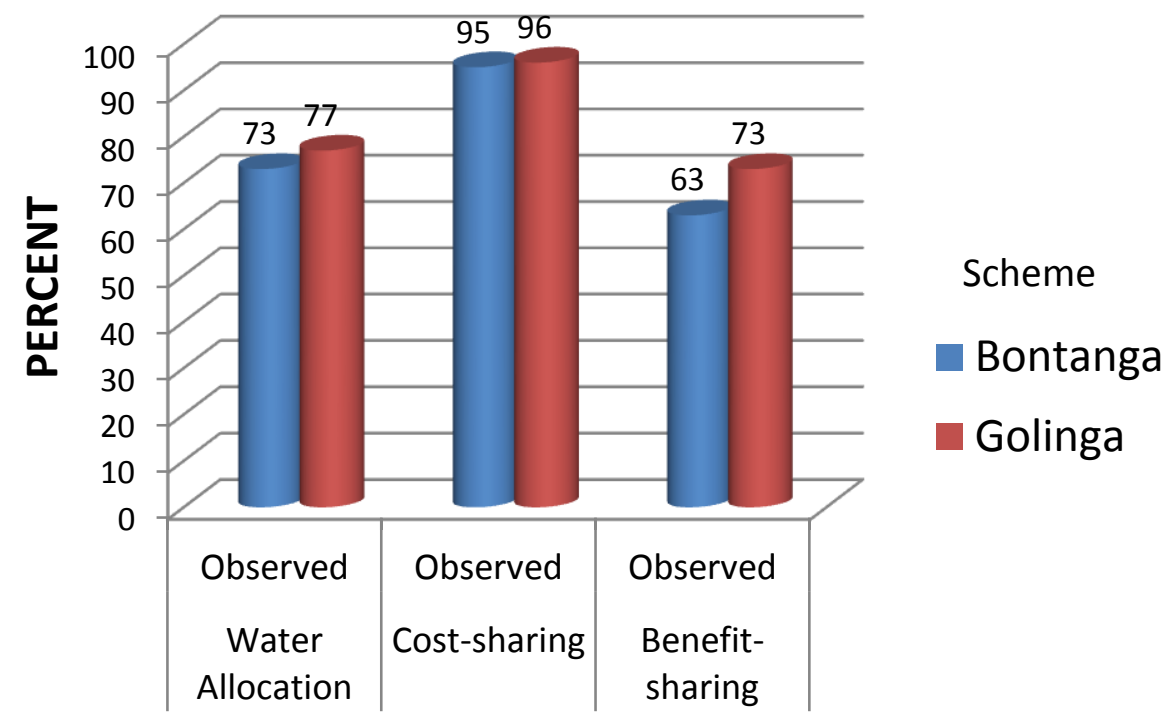

\section{EQUITY}

The farmers who claimed there was no equity in water allocation, cost and benefit sharing gave common reasons as upstream superiority, favouritism and discrimination against women. 


\section{Equity in plot allocation}

On the distribution of irrigated plots among the farmers, the study found that female farmers on the project did not have equal access, ownership and use of land, mainly because women are traditionally not landowners. Furthermore, men as heads of households and breadwinners expect their wives to work on the men's farms since the income from their (the men) farms takes care of the entire household while the income from the women's farms is meant for the women alone.

Whereas the highest farm-holding size among the female respondents at Bontanga was 0.4 hectares, it was 1 hectare or more among their male counterparts. As well as the women farmers owning smaller plots, some of them gained access to their irrigated plots only through the entitlements of their husbands. It can therefore be concluded that there is insecurity of tenure for the women farmers. This conforms to the findings of Wahaj et al (2007) that in water-scarce regions and countries of subSaharan Africa and South Asia, inequity in access to water resources is increasing because of competition for the limited resource and that it is particularly affecting the rural poor, especially women. There is a widely held notion that women's access to water and land is central to achieving the Millennium Development Goals, in particular Goal 1 (reducing by half the proportion of people living in extreme poverty and hunger by 2015) and Goal 3 (promoting gender equality and empowering women) (Wahaj et al., 2007). Thus, providing women with their own irrigated plots will not only ensure that such women take better control of the fruits of their labour in irrigated agriculture (Zwarteveen, 1996). The implication of this marginalisation of women in access to irrigated land is that women's participation in irrigated farming and irrigation management decisions will be limited, which ultimately will impact negatively on their ability to feed and support their families. This will certainly thwart all efforts at using irrigated farming as a tool for poverty reduction among the poor especially women - and the sustenance of the PIM strategy.

\section{Transparency}

As indicated in Figure 4 the study revealed that $63 \%$ and $65 \%$ of the farmers at Bontanga and Golinga, respectively agreed that there was transparency in the management of the 'water fee'fund. Golinga is doing a little better than Bontanga. However, with respect to transparency in the management of the "water fee" fund the views are varied. While $69 \%$ of the farmers at Golinga said there was transparency, almost the same proportion of farmers (61\%) at Bontanga claimed that there was no transparency in the management of their "water fee" fund. The farmers who claimed there was no transparency in the fund management cited limited disclosure of financial transactions to farmers as the main reasons for their views. Conversely those who claimed there was transparency in the fund management cited regular and adequate disclosure of financial transactions to farmers as their reason. This finding agrees with many reports including that of Hamada and Samad (2011) that transparency in the account conditions in WUAs was among the reasons for low rates in water fee collection. 
Figure 4: Transparency in financial issues in Bontanga and Golinga Source: Field survey, 2012

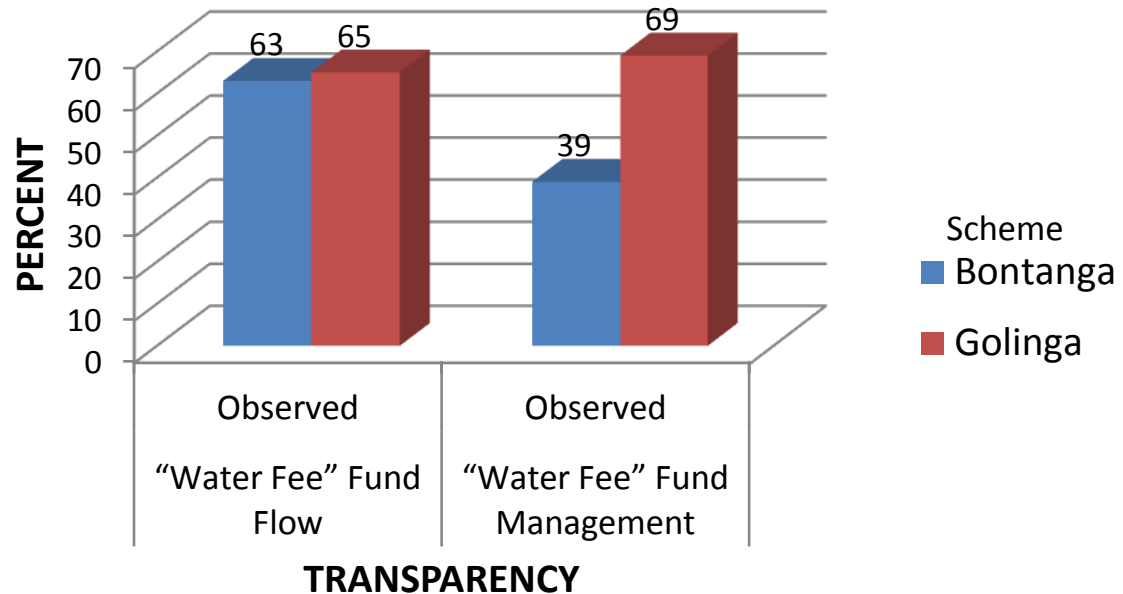

In fact, the application of the principles of equity and transparency at both schemes need improvement. This could be achieved by ensuring that the financial situation is reported to the farmers especially at Bontanga. Indeed, Sato et al. (2007) cited in Hamada \& Samad (2011) stressed that equity and transparency in water allocation and costs sharing among members were essential for sustainable PIM.

\section{Representation}

Farmers' representation or voice in decision making creates opportunity for them to influence decisions, and also allows them access to relevant information in order to make rational decisions and protect their interests. While $50.8 \%$ of the respondents at Bontanga confirmed being represented in the decision-making process, $49.2 \%$ disagreed (Table 3). At Golinga, 65.4\% of the respondents confirmed their representation in the decision-making process, but $34.6 \%$ disagreed. For both schemes, a little over half (i.e. 55\%) of the respondents confirmed their representation in the decisionmaking process. The large proportion claiming no representation (i.e. 45\%) was mainly due to the large number of farmers from Bontanga claiming that they were not adequately represented in the decision making process. In terms of gender representation, as many as $56 \%$ of the 62 men sampled were represented while only $48 \%$ of the 23 women sampled were represented.

Table 3: Representation in decision making by sex. Source: Author's field survey, May 2012

\begin{tabular}{|l|l|l|l|l|l|l|}
\hline \multirow{2}{*}{ Scheme } & Female & \multicolumn{2}{|c|}{ Male } & \multicolumn{2}{c|}{ Total } \\
\cline { 2 - 7 } & Representation & $\begin{array}{c}\text { No } \\
\text { Representation }\end{array}$ & Representation & $\begin{array}{c}\text { No } \\
\text { Representation }\end{array}$ & Representation & $\begin{array}{c}\text { No } \\
\text { Representation }\end{array}$ \\
\hline Bontanga & $4(6.8 \%)$ & $7(11.9 \%)$ & $26(44 \%)$ & $22(37.3 \%)$ & $30(50.8)$ & $29(49.2)$ \\
\hline Golinga & $8(30.8 \%)$ & $4(15.4 \%)$ & $9(34.6 \%)$ & $5(19.2 \%)$ & $17(65.4)$ & $9(34.6)$ \\
\hline Total & $12(14.1 \%)$ & $11(12.9 \%)$ & $35(41.2 \%)$ & $27(31.8 \%)$ & $47(55.3)$ & $38(44.7)$ \\
\hline
\end{tabular}

Since the proportion of farmers in Bontanga who were represented in the decision making process (50.8\%) was far less than the proportion represented in Golinger (65.5\%) it can be deduced that the democratic values in Golinga were better than that of Bontanga. 


\section{Mainstreaming gender in irrigation farming in northern Ghana}

Mainstreaming gender in agriculture in Ghana's Northern Region will not achieve much because of cultural reasons, as society considers agriculture a preserve for men whilst food processing is the preserve of women. It is argued here that participatory development is effective only where democratic processes allow for equal representation of beneficiary farmers in the decision-making process irrespective of gender, ethnicity and location, but this is not achieved in the projects studied.

The study revealed that apart from the fact that the male farmers outnumbered females, when it comes to their involvement in decision making the proportions are in favour of the male farmers. While as many as $56.5 \%$ (i.e. 35 ) of the 62 male farmers said they were represented only $52.2 \%$ (i.e. 12 ) of the 23 female farmers claimed to be represented in the decision making process. Contrary to the view of Wahaj et al. (2007) that women like men, may also have clear opinions about how an irrigation system should be operated, their viewpoint is not likely to be articulated in both Bontanga and Golinga since the absolute number of females (23) is very small as compared to the males (675).

\section{Local socio-political dimensions of PIM}

The IDA Regulations, 1987 (L.I. 1350) stipulates that the District Chief Executive be the Chairman of the Lands Allocation Committee. Also the membership of the Committees must include a representative of the Traditional Council within the area. It is common knowledge that membership of the Farmers' Association includes opinion leaders, wealthy and other influential persons from political parties, associations, the clergy and chiefs, among others. This suggests that socio-political conflicts find their way into the functioning of the Farmers' Associations and/or the committees. The study revealed that $17 \%$ of the members of the FBOs/Committees encountered some socio-political pressure in the performance of their assigned roles. The management of the irrigation schemes was not without local political influence. The implication here is that scheme managers have to go beyond the established bureaucratic/administrative structures into the host communities to negotiate with local socio-political institutions and individuals for the resolution of certain disputes that confront them.

The farmers hinted that socio-political pressures are usually associated with issues such as the collection of irrigation service charges, land management and allocation, reservoir water use and protection, and conflict resolution and management. The study further revealed that the Chieftaincy institution and some influential individual farmers impede the effective functioning of the local-level participatory management structures. In handling such circumstances, the leadership of the committees/association resorted to the use of bureaucratic/administrative structures of the schemes. However, some executives were quick to add that some disputes never get resolved effectively and satisfactorily. This, they said, sometimes results in farmers disregarding certain rules and regulations. 
The leadership maintained that such negative pressure from local institutions disturb the relationship between the communities and the schemes. It is important to note that in northern Ghana, culturally leadership of local institutions are the domain of and preserve for men and as such contributes to the marginalisation of women in decision making processes and consequently the benefits associated with the implementation of the PIM. The PIM therefore is gender-blind and has the tendency to promote further marginalisation of women in the implementation of its functions. For the women participating in PIM to enhance their potential in supporting the irrigation projects, they need to participate on equal footing where exclusion and inequality are not entertained.

\section{Roles and responsibilities of PIM stakeholders}

In addition, it was noted that in assigning roles and responsibilities to various stakeholders there appeared to be too much concentration on the discussion of the Irrigation Services Charge (ISC) at the expense of other equally important issues necessary for sustaining the irrigation projects. For example, one of the responsibilities of the stakeholders is 'organisation of regular meetings to discuss the status of facilities and identify problems, if any".

Local government appeared to be playing very minimal role although the irrigation communities belong to their constituencies. This is an opportunity for the stakeholders to discuss issues directly related to the irrigation projects, and to raise other indirect issues. For example the opportunity created could be used to sensitise stakeholders of the PIM especially FBOs about the current trends in water supply and its implication for the projects, and the potential role that the District Assembly could play in PIM. Water was identified as the most vulnerable sector being affected by climate change (Intergovernmental Panel on Climate Change Fourth Assessment Report, 2007). The threats exacerbate the 'multiple stressors' of development, such as widespread poverty. This has implications for the local governments of the communities as well as communities that are dependent on irrigation-based agriculture and natural resources for food security and daily livelihoods. Therefore, adequate and timely action to adapt to climate -change induced water stress is of crucial importance, and the stakeholders in this project could make use of the existence of PIM structures to creat 4 awareness of global environmental trends and the local vulnerability to climate change of the farming communities, local government and other stakeholders. 


\section{Recommendations}

The paper observed that there are some weaknesses in the implementation of PIM, which need to be addressed to make it more efficient and effective. Some weaknesses are related to participation/ representation, functions/roles and marginalisation of some key stakeholders such as the District Assembly and women participants. A number of recommendations were therefore made to address these weaknesses. As women farmers having difficulty in owning, accessing and using irrigated lands, it is proposed that the Ghana Irrigation Development Authority (GIDA) and District Assembly adopt gender mainstreaming policies that encourage women participation in irrigated agriculture by facilitating equal access to irrigated plot(s) in the scheme area. To facilitate the implementation of this policy GIDA needs to build women farmers' capacity in leadership and build confidence to ensure their effective participation in decision-making in PIM. GIDA should make deliberate efforts to include women farmers in all technical farming skills training programmes. The gender mainstreaming efforts must also address the fear that overall agricultural productivity will decline if women were given their own irrigated plots because they will reduce their labour contributions to their husbands' farms in favour of working on their own plots (Zwarteveen, 1996). Where the interest of females in agriculture is encouraging, mainstreaming efforts could consider establishing a quota system to facilitate women's access to irrigated lands, with the support of the district assembly. GIDA should also consider the establishment of women's committees to cater for their special needs if any.

With regards to irrigation regulations, it is recommended that the IDA Regulations, 1987 (L.I. 1350) be revised to take into account present and future dynamics in participatory management of irrigation schemes. The revision should, among other things, give adequate space and legal backing to the scheme managers and the Farmers Associations so that they can strengthen existing committees and organizations at the local levels. The revision should harmonise all the functions of the Farmers Associations including the various committees.

In the case of the unwillingness of many of the irrigation farmers to take on additional responsibilities, it is recommended that the government through GIDA should take steps to restructure the Farmers Associations by bringing on board commercial farmers or groups. The the government of Ghana should adapt an integrated model comprising, for example, the Japanese and Mexican Models of PIM for implementation. GIDA should also empower the scheme managers to consider raising funds from the farmers to pay for incentives for participation in additional responsibilities, as assigning additional responsibilities without incentives is unsustainable.

GIDA should enforce regular and full disclosure of all financial transactions pertaining to the water fee management. This can be done through the help of the District Assembly, and improved reporting systems and this is the only way to remove the feeling of lack of transparency. Also, in order to enhance representation in decision-making, GIDA must find ways of encouraging and broadening 
ordinary farmers' participation in all activities including decision making with regard to scheme management (Wijayaratna, 2000, cited in Asian Productivity Organisation, 2002). The use of ISC payment in benefits sharing should be encouraged in all schemes because it has positive effects on the promotion of equity.

Lastly, since irrigation schemes are located within the vicinity of some communities it may not be possible to insulate them against local socio-political influences. Therefore, the occasional encounter with local socio-political groups, such as the traditional leaders and the District Authorities should be considered unavoidable and turned into opportunities to establish and deepen communityproject/scheme relationship. Thus, scheme managers and FBOs/Committee executives must go beyond the established bureaucratic/administrative structures into the host communities and negotiate with local institutions and individuals for the resolution of certain disputes or conflicts that confront them.

It is also recommended that some of the meetings of FBOs and farmers cooperatives should be used as opportunity to sensitise the members and the community at large about some of the global issues related to water stress and sustainability due to climate change and provide guidance - mitigation measures - as to how to protect their irrigation projects against some of these problems.

Furthermore, it is recommended that GIDA, in consultation with the Farmers' Associations set aside $5 \%$ of total 'water fee' collected annually as 'Benefit Package' to be shared rotationally among the chiefs of host communities of irrigation projects for other community projects. The package will serve as royalties as the chiefs and their people were not compensated for the loss of their lands and water resources entitlements during the establishment of the schemes. This will serve not only as a sustainable strategy that duly recognises the chiefs as the custodians of the lands in their communities, but also consolidate their support and participation in the management of schemes.

\section{Conclusion}

The study established that Participatory Irrigation Management (PIM) was actively being pursued in the Bontanga and Golinga irrigation schemes of the Tolon-Kumbungu District. Furthermore, both GIDA and the farmers are enjoying the production and social benefits of PIM, which should ideally lead to improved operations and management of the irrigation infrastructure. The study has also established that the PIM strategy was more effective and sustainable at Golinga than at Bontanga. The study concludes that more than half of all the farmers interviewed appeared reluctant to assume additional responsibilities without remuneration. Therefore the study concludes that local participatory management is unlikely to sustain the PIM strategy if key activities are not properly valued and appropriately remunerated. This is a critical area that government must rethink if the PIM strategy is to be sustained in Ghana. 


\section{References}

Asian Productivity Organisation (2002). Organisational Change for Participatory Irrigation Management: A Report of the Asian Productivity Organisation Seminar on Organisational Change for Participatory Irrigation Management. Philippines, 23-27, October, 2000. Published by Asian Productivity Organisation (APO): Philippine

Braimah, I. and N. Filmua (2011), Community Ownership and Management of Water and Sanitation Facilities: Issues and Prospects in the Nadowli District of the Upper West Region of Ghana, Journal of Sustainable Development in Africa, Vol. 13(3) pp 74-87.

Hamada, H and Samad, M. (2011) Basic principles for sustainable participatory irrigation management. A Research review, JARQ 45(4), 371-376. Accessed 02/02/2012 from www.jircas.affrc.go.jp/english/publication/jarq/45-4/45-04-03.pdf

Japan International Cooperation Agency (2004) Historical changes in the technical cooperation provided to Ghana's irrigated agriculture sector. Accessed 4/10/2011 http://jica-ri.jica.go.jp/IFIC_and_JBICIStudies/english/publications/reports/study/capacity/200609/pdf/200609_04e.pdf

Lamptey, D.; Nyamdi, B. and Minta, A. (eds.) (2011) National Irrigation Policy, Strategies and Regulatory Measures. Published by the Ghana Irrigation Development Authority of the Ministry of Food and Agriculture, Accra, Ghana. Accessed 21/9/2011 http://mofa.gov.gh/site/wpcontent/uploads/2011/07/GHANA-IRRIGATION-DEVELOPMENT-POLICY1.pdf

Ministry of Agriculture (2011) The Inventory of Irrigation Schemes in Ghana. Published by MoFA, Accra. Accessed from www.mofa.org.gh on 10/10/2011

Peter, J.R (2004) Participatory Irrigation management: Lessons from International Experience. Paper presented at the workshop on "PIM-pathways to progress" organized by the Asian Development Bank, Hanoi, Vietnam, March 31- April 2, 2004. Accessed 5/10/2011 www.maff.go.jp/e/nousin/kaigai/inwepf/i_document/pdf/sympo_inpim.pdf

Tanaka, Y. and Sato, Y. (2002). A case study of Japanese Irrigation Association as a model of participatory irrigation management. A research article published by The Graduate School of Agricultural and Life Science, University of Tokyo

The IDA Regulations, 1987 (L.I.1350) published by GIDA, Accra

The Republic of Ghana (2006) Draft National Irrigation policy, Strategies and Regulatory Measures. Published by the Ministry of Food and Agriculture, Accra

The Republic of Ghana (2012) The Ghana Districts Profile. Accessed on 01/08/2012 from www.ghanadistricts.gh

Vermillion, D.L. (1997) Impacts of irrigation management transfer: A review of the evidence. IIMI Research Report No.11. Colombo, Sri Lanka: International Irrigation Management Institute. Accessed 23/9/2011 http://dlc.dlib.indiana.edu/dlc/bitstream/handle/10535/3920/REPORT11.pdf?sequence=1

Wahaj, R.; Hartle, M.; Lubbock, A.; Cleveringa, R. and Nepveu, A. (2007) Securing water for improved rural livelihoods: The multiple-uses system approach. A gender and water publication by the International Fund for Agriculture Accessed 21/10/2011 www.ifad.org/gender/thematic/water/gender_water.pdf

Zwarteveen, M. Z. (1996) A Revised Report from 'A plot of one's own: Gender relations and irrigated land allocation policies in Burkina Faso, Research Report 10'. Washington DC: The Consultative Group on International Agricultural Research (CGIAR). 